\author{
Ana Cláudia Soncini Sanches*, \\ Cassiana Regina de Góes, Marina \\ Nogueira Berbel Bufarah, André Luis \\ Balbi and Daniela Ponce \\ University Sao Paulo State-UNESP, Distrito de \\ Rubiao Junior, without number, Botucatu, Sao \\ Paulo, Brazil \\ Dates: Received: 20 June, 2016; Accepted: 15 July, \\ 2016; Published: 16 July, 2016 \\ *Corresponding author: Ana Cláudia Soncini \\ Sanches, Distrito de Rubiao Junior, without number, \\ Botucatu, Sao Paulo, Brazil, Tel: 5518 981599205; \\ E-mail: anaclaudiasoncini@yahoo.com.br \\ www.peertechz.com \\ ISSN: 2455-5495 \\ Keywords: Energy expenditure; Acute kidney injury \\ Sepsis
}

\section{Research Article \\ Does Acute Kidney Injury Alter Energy Metabolism of Septic Patients?}

\section{Introduction}

Sepsis, defined as systemic inflammatory response syndrome associated with infection, is an important cause of morbidity and mortality in patients admitted to intensive care units (ICU) [1,2].

It is the most frequent cause of acute kidney injury (AKI) in critically ill patients, occurring in approximately $51 \%$ of patients with septic shock and positive cultures. Septic patients developing severe AKI have increased risk of mortality, despite advanced vital organ support $[3,4]$.

It is well know that sepsis and AKI can affect the energy metabolism and treatments based on a better understanding of these alterations may help to prevent weight loss and muscle wasting [5]. Accurate determination of energy needs is obviously important in critically ill patients because both over and underfeeding may be associated with complications and undesirable consequences such as over and underfeeding [6].

Energy metabolism in patients with renal failure has been studied, with conflicting results [7-14]. Studies have suggested that chronic kidney disease (CKD) is associated with hypometabolic state due to abnormalities in cell metabolism [10,11]. In contrast, a hypermetabolic state was frequently observed in AKI patients and associated with cause and severity [15]. The hypermetabolism may be present in AKI patients since AKI is a part of a more complex illness such as sepsis and not necessarily the direct consequence of renal failure per se [15-21]. Thus, it is unknown whether possible changes in energy metabolism observed in septic patients with AKI are directly related to AKI itself.

Given the lack of studies on energy metabolism in AKI patients, we decided to measure and compare the resting energy expenditure (REE) in septic patients with and without AKI using indirect calorimetry (IC). This study also aims to compare the REE estimated by the Harris-Benedict equation (HB) with that measured by IC.

\section{Patients and Methods}

A prospective, observational study was conducted from November 2013 to May 2015 in patients admitted to ICUs from a Brazilian University Hospital.

Patients 18 years of age or older who had sepsis according to "Survival Sepsis Campaign 2012 [22] and mechanically ventilated using of inspired oxygen $\left(\mathrm{FiO}_{2}\right)<0.60$ were included in the study. Exclusion criteria were patients with CKD stage 4 and 5 (creatinine clearance lower than $30 \mathrm{~mL} / \mathrm{min} / 1.73 \mathrm{~m}^{2}$, estimated by the modification of diet in renal disease (MDRD) equation) [23].

Septic patients were divided into two groups according to presence or absent of AKI. AKI was defined using KDIGO 2012 criteria [24]. 
Variables previously reported to be associated with AKI, sepsis or energy metabolism were collected prospectively on each patient by review of the medical record: sex, age, the presence of comorbidities (diabetes, CKD, and hypertension), primary diagnosis, the a etiology of sepsis, prognostic score specific for AKI (ATN-ISS) [25], Sequential Organ Failure Assessment (SOFA) [26], use of vasoactive drug and neuromuscular blocking agents, serum creatinine and blood urea nitrogen levels, $\mathrm{C}$ reactive protein (CRP) and leukocytes.

The REE was estimated by HB equation [27] and measured by the IC within 72 hours after the diagnosis of sepsis and seven days after the initial measure. IC was performed using QUARK RMR (Cosmed, Rome, Italy). The calorimeter was calibrated before each use. The protocol required that patients be inactive and undisturbed for 30 minutes prior to testing and for 30-minute duration of the data collection. It is recommended that patients achieve steady state during testing. Steady state was defined as a variability of $<10 \%$ in the measurements of oxygen consumption and carbon dioxide production, and $<5 \%$ in the respiratory quotient from minute to minute. The REE was also estimated using HB formula and injury factor for sepsis as suggested by Long et al. [28].

Patient height was measured when possible, or it was considered the value documented in the medical record at the time. Weight was measured using calibrated hospital scales in most patients or estimated using Chumlea formula [29].

The Ethics Committee of the Botucatu School of Medicine UNESP approved this study (approved protocol number 322.535) with a waiver of informed consent given its observational nature.

\section{Statistical analysis}

The sample size calculated was 61 patients considering standard deviation $200 \mathrm{kcal}$, estimated maximum error de $50 \mathrm{kcal}$ in critically ill patients and $\mathrm{p}$ value $=0.05$.

Data analysis was performed using SAS for Windows (version 9.2: SAS Institute, Cary, NC, USA, 2012). Results were expressed as mean and standard deviation or median and interquartile range. The chi-square test was used to compare categorical variables. We used ANOVA to compare parametric variables of clinical, laboratory and nutritional data. For non-parametric variables, the Mann-Whitney test was used. Variables with significant univariate associations $(\mathrm{p}<0.10)$ were candidates for multivariable analysis, which was performed using stepwise variable selection. Repeated measures analysis using the mixed procedure was used for the evolutional REE. For all tests, a p-value of $<0.05$ was considered statistically significant.

\section{Results}

Sixty-eight septic patients admitted to ICU were evaluated. Mean age was $62.49 \pm 16.6$ years, $64.7 \%$ were male, $88.24 \%$ were Caucasian, SOFA was $9.81 \pm 2.35$, shock septic was the classification of sepsis more frequent $(64.71 \%)$, lung was the main site of infection $(70.6 \%)$ and comorbidities were present in $82.85 \%$ of patients. The measured REE was 1857 (1308-2261.5) kcal, while the estimated REE was 1449 (1255.5-1677.5) kcal. AKI was present in majority of patients (63.2\%) and mortality was high (77.94\%). Most of AKI patients was KDIGO stage 3 (60.5\%), 30.2\% were KDIGO2 and only four patients were
KDIGO 1 (9.3\%). Nine patients needed renal replacement therapy and all of them were treated with intermittent hemodialysis. A comparison of baseline characteristics between those who did and did not develop AKI is shown in Table 1.

AKI group had higher SOFA ( $11.0 \pm 1.73$ vs. $7.76 \pm 1.79, \mathrm{p}<0.0001)$, CRP ( $\mathrm{p}=0.0107)$, comorbidities $(\mathrm{p}=0.0179)$ and mortality $(\mathrm{p}=0.046)$. The groups were similar in gender, age and site of infection. In multivariable regression analysis, comorbidities (OR: 0.07; CI95\%: 1.0-1.8) and SOFA (OR: 0.32; CI95\%: 0.1-0.5) were identified as predictors of AKI (Table 2).

The Table 3 shows the comparison between estimated and measured REE in both groups of patients. Septic patients without

Table 1: Patients demographics and clinical characteristics $(n=68)$ according to presence of $\mathrm{AKI}$.

\begin{tabular}{|c|c|c|c|c|}
\hline Variables & $\begin{array}{l}\text { Septic } \\
\text { patients } \\
(n=68)\end{array}$ & $\begin{array}{l}\text { AKI septic } \\
\text { patients } \\
(\mathrm{N}=43)\end{array}$ & $\begin{array}{l}\text { Non-AKI } \\
\text { septic patients } \\
(\mathrm{N}=25)\end{array}$ & $\mathbf{P}$ \\
\hline Age (years) & $62.49 \pm 16.60$ & $65.28 \pm 14.50$ & $57.68 \pm 19.05$ & 0.07 \\
\hline Male sex (\%) & $44(64.71)$ & 27 (62.79) & $17(68.0)$ & 0.66 \\
\hline $\begin{array}{l}\text { Race (\%) } \\
\text { Caucasian }\end{array}$ & 60 (88.24) & 38 (88.37) & $22(88.0)$ & 0.91 \\
\hline $\begin{array}{l}\text { Sepsis classification } \\
(\%) \\
\text { Septic shock } \\
\text { Sepsis } \\
\text { Sepsis }\end{array}$ & $\begin{array}{l}44(64.71) \\
24(35.29)\end{array}$ & $\begin{array}{l}26(60.47) \\
17(39.53)\end{array}$ & $\begin{array}{l}18(72.0) \\
7(28.0)\end{array}$ & 0.41 \\
\hline \multicolumn{5}{|l|}{ Site of infection (\%) } \\
\hline Pulmonary & 48 (70.59) & $26(60.47)$ & $22(88.0)$ & 0.0857 \\
\hline Abdominal & $14(20.59)$ & $11(25.58)$ & $3(12.0)$ & 0.079 \\
\hline Others & $6(8.82)$ & $6(13.95)$ & - & 0.13 \\
\hline SOFA score* & $9.81 \pm 2.35$ & $11.0 \pm 1.73$ & $7.76 \pm 1.79$ & $<0.001$ \\
\hline $\begin{array}{l}\text { Presence } \\
\text { Comorbidities (\%) } \\
\text { Hypertension } \\
\text { Diabetes Mellitus } \\
\text { Dyslipidemia } \\
\text { Obesity }\end{array}$ & $\begin{array}{l}56(82.85) \\
42(61.76) \\
18(26.47) \\
13(19.11) \\
8(11.76)\end{array}$ & $\begin{array}{l}39(90.7) \\
31(72.09) \\
15(34.88) \\
10(23.25) \\
6(13.95)\end{array}$ & $\begin{array}{l}17(68.0) \\
11(44.0) \\
3(12.0) \\
3(12.0) \\
2(8.0)\end{array}$ & $\begin{array}{l}0.017 \\
0.024 \\
0.097 \\
0.15\end{array}$ \\
\hline $\begin{array}{l}\text { Ventilation mode (\%) } \\
\text { Controled } \\
\text { Spontaneous }\end{array}$ & $\begin{array}{l}54(79.41) \\
14(20.59)\end{array}$ & $\begin{array}{l}36(83.72) \\
7(16.28)\end{array}$ & $\begin{array}{l}18(72.0) \\
7(28.0)\end{array}$ & 0.2491 \\
\hline $\mathrm{FiO}_{2}$ & $35.97 \pm 9.49$ & $35.84 \pm 9.59$ & $36.20 \pm 9.50$ & 0.8805 \\
\hline $\begin{array}{l}\text { Use of vasoactive } \\
\text { drugs (\%) }\end{array}$ & $50(73.53)$ & 34 (79.07) & $16(64.0)$ & 0.1744 \\
\hline Use of sedatives (\%) & $34(50.0)$ & $21(48.84)$ & $13(52.0)$ & 0.5000 \\
\hline Use of antibiotics (\%) & 65 (95.59) & 41 (95.35) & $24(96.0)$ & 0.6967 \\
\hline Presence of fever (\%) & $46(67.64)$ & $29(67.44)$ & $17(68.0)$ & 0.5906 \\
\hline $\begin{array}{l}\text { Blood Urea Nitrogen } \\
\text { (mg/dl) }\end{array}$ & $62.82 \pm 38.46$ & $75.28 \pm 29.32$ & $3.72 \pm 17.50$ & $<0.001$ \\
\hline Creatinine (mg/dl) & $2.35 \pm 1.68$ & $3.22 \pm 1.51$ & $0.84 \pm 0.32$ & $<0.001$ \\
\hline CRP $(\mathrm{mg} / \mathrm{dl})^{\star *}$ & $29.27 \pm 15.72$ & $32.94 \pm 14.63$ & $22.98 \pm 15.82$ & 0.0107 \\
\hline Leukocytes $\left(\mathrm{mm}^{3}\right)$ & $\begin{array}{l}16392.81 \pm \\
8761.79\end{array}$ & $\begin{array}{l}17226.63 \pm \\
9240.82\end{array}$ & $\begin{array}{l}14992 \pm \\
7872.42\end{array}$ & 0.3163 \\
\hline $\begin{array}{l}\text { Outcomes (\%) } \\
\text { Death }\end{array}$ & $53(77.94)$ & 38 (88.37) & $15(60.0)$ & 0.046 \\
\hline
\end{tabular}

*Sequential Organ Failure Assessment Score; **Acute Kidney Injury; *** C Reactive Protein reactive, $\mathrm{FiO}_{2}$ fraction of inspired oxygen. 
AKI ( $\mathrm{n}=25)$ and with AKI $(\mathrm{n}=43)$ had measured REE significantly higher than estimated one (1855.0 kcal (1636.75-2052.75) vs. 1551.0 (1349.0 -1719.25), $\mathrm{p}=0.007$ and $1868.0 \mathrm{kcal}(1219.5-236475)$ vs. $1388.0 \mathrm{kcal}$ (1254.0-1665.5), $\mathrm{p}=0.026$, respectively). The HB equation without using injury factor was not precise and underestimated the REE in $16.4 \%$ in septic patients without AKI and in $25.7 \%$ in septic patients with AKI.

However, when injury factor was used, the measured REE was significantly lower than estimated one in both groups. Measured and estimated REE were 1855 (1636.75 - 2052.75) vs 2467.2(13222213.8), $\mathrm{p}<0.001$ in non-AKI group and 1868.0 (1219.5 - 2364.75) vs. 2370.63(1456-2451), $\mathrm{p}<0.001$ in AKI group. Thus, the HB equation using injury factor was not precise and overestimated the REE in 33\% in septic patients without AKI and in $26.9 \%$ in septic patients with AKI.

There was no significant difference between the two groups (with and without AKI) in measured and estimated REE ( $p=0.6268$ and 0.6360, respectively). This suggests that AKI does not affect the REE septic patients.

There was no significant difference in evolutional REE (day 1 vs. day 7) in general septic population (1845.955 $\pm 658.273 \mathrm{kcal}$ vs. $1809.545 \pm 755.083 \mathrm{kcal}, \mathrm{p}=0.865)$ and after patients were divided into AKI (1873.5 \pm 718.43 vs.1610.5 $\pm 629.98, \mathrm{p}=0.706)$ and non-AKI groups ( $1795.833 \pm 557.734$ vs. $1915 \pm 756.215, \mathrm{p}=0.76$ ) (Table 4 ).

\section{Discussion}

This study described and compared the REE estimated by the HB equation and measured by IC in septic patients who developed and did not develop AKI during ICU stay. Its results indicate that $\mathrm{HB}$ equation does not agree well with energy expenditure measured by IC in critically ill patients and that AKI itself apparently has no direct effect on energy metabolism of septic patients.

The measured REE was higher than the estimated one in general septic population and in groups that developed and did not developed AKI. The equation HB without using injury factor was not precise and underestimated the REE in both groups: septic patients without and with AKI.

Due to the inaccuracy of this equation, the correction factor was applied. However, when injury factor was used, the measured REE was statistically lower than the estimated one in all groups. Thus, the equation $\mathrm{HB}$ using injury factor was not precise and overestimated the REE in both groups: septic patients who did not develop AKI and in that developed AKI.

Similar results have been observed in previous studies [30-33]. Coletto et al. [30], reported in septic patients that $\mathrm{HB}$ equation underestimated the REE in $7.6 \%$ and when the injury factor as used, the REE was overestimated in more than $50 \%$. In a systematic review, Frankenfield et al. [31], reported the results of an evidence analysis of the accuracy of metabolic rate calculation methods. HB equation had mean differences between measured resting metabolic rate and predicted values ranging from 250 to $900 \mathrm{kcal} /$ day. A review study conducted by Walker and Heuberger suggests not to use the
Table 2: Multivariable analysis for AKI risk $(n=68)$.

\begin{tabular}{|l|l|l|l|}
\hline Factors & OR & Cl 95\% & p \\
\hline Site of infection & 0.4 & $0.09-1.7$ & 0.2284 \\
\hline $\begin{array}{l}\text { Presence of } \\
\text { comorbidities }\end{array}$ & 0.07 & $1.0-1.8$ & 0.0327 \\
\hline CRP* & 0.94 & $0.88-1.0$ & 0.0620 \\
\hline SOFA score ** & 0.32 & $0.1-0.5$ & 0.0002 \\
\hline $\begin{array}{l}\text { Note: OR: odds ratio; Cl95\%: confidence interval of 95\%; p: statistical } \\
\text { significance } \\
\text { *C Reactive Protein reactive; **Sequential Organ Failure Assessment Score. }\end{array}$ \\
\hline
\end{tabular}

Table 3: Anthropometric characteristics and resting energy expendure of septic patients admitted to intensive care unit according to presence of AKI.

\begin{tabular}{|c|c|c|c|c|}
\hline Variables & $\begin{array}{l}\text { Septic } \\
\text { patients } \\
(n=68)\end{array}$ & $\begin{array}{l}\text { AKI septic } \\
\text { patients }(n=43)\end{array}$ & $\begin{array}{l}\text { Non-AKI } \\
\text { septic patients } \\
(n=25)\end{array}$ & $\mathbf{P}$ \\
\hline Weight (Kg) & $76.74 \pm 25.40$ & $77.23 \pm 26.35$ & $75.88 \pm 24.17$ & 0.83 \\
\hline Height (cm) & $157.82 \pm 35.23$ & $160.87 \pm 27$ & $152.58 \pm 46$ & 0.35 \\
\hline BMI $\left(\mathrm{Kg} / \mathrm{m}^{2}\right)^{*}$ & $27.83 \pm 8.59$ & $28.04 \pm 7.97$ & $27.48 \pm 9.55$ & 0.72 \\
\hline $\begin{array}{l}\text { Measured REE } \\
(\mathrm{kcal})^{\star \star}\end{array}$ & $\begin{array}{l}1857(1308- \\
2261.5)^{a}\end{array}$ & $\begin{array}{l}1868(1219.5- \\
236475)^{b}\end{array}$ & $\begin{array}{l}1855(1636.75- \\
2052.75)^{c}\end{array}$ & 0.63 \\
\hline $\begin{array}{l}\text { Estimated REE } \\
\text { (kcal) }\end{array}$ & $\begin{array}{l}1449 \text { (1255.5- } \\
1677.5)\end{array}$ & $\begin{array}{l}1388(1254.0- \\
1665.5)\end{array}$ & $\begin{array}{l}1551(1349.0 \\
-1719.25)\end{array}$ & 0.63 \\
\hline $\begin{array}{l}\text { Estimated REE } \\
\text { using IF (kcal) }\end{array}$ & $\begin{array}{l}\text { 2283.2(1308- } \\
2261.5)\end{array}$ & $\begin{array}{l}2370.63(1456- \\
2451)\end{array}$ & $\begin{array}{l}\text { 2467.2(1322- } \\
2213.8)\end{array}$ & 0.59 \\
\hline \multicolumn{5}{|c|}{$\begin{array}{l}\text { * Body Mass Index; ** Resting Energy Expenditure; } \\
\text { a Different from estimated REE using HB formula without and with injury factor, } \\
p<0.001 \\
{ }^{b} \text { Different from estimated REE using HB formula without and with injury factor, } \\
p=0.007 \text { and }<0.001 \text { respectively. } \\
\text { c Different from estimated REE using HB formula without and with injury factor, } \\
p=0.026 \text { and }<0.001 \text { respectively. } \\
\text { IF: injury factor. }\end{array}$} \\
\hline
\end{tabular}

Table 4: Evolutional resting energy expendure (day 1 vs day 7 ) in septic patients according to presence of AKI.

\begin{tabular}{|l|l|l|l|}
\hline & \multicolumn{2}{|l|}{ After seven days } & \\
\hline & $\begin{array}{l}\text { measured REE } \\
\text { D1 (kcal) }\end{array}$ & $\begin{array}{l}\text { measured REE } \\
\text { D7 (kcal) }\end{array}$ & P \\
\hline Séptic patients $(\mathbf{n}=\mathbf{2 2})$ & $1845.955 \pm 658.273$ & $1809.545 \pm 755.083$ & 0.865 \\
\hline $\begin{array}{l}\text { AKI* septic patients } \\
(\mathbf{n}=\mathbf{1 6})\end{array}$ & $1873.5 \pm 718.43$ & $1610.500 \pm 629.98$ & 0.706 \\
\hline $\begin{array}{l}\text { Non-AKI septic } \\
\text { patients }(\mathbf{n}=6)\end{array}$ & $1795.833 \pm 557.734$ & $1915.000 \pm 756.215$ & 0.762 \\
\hline
\end{tabular}

*Acute Kidney Injury, *REE: rest energy expenditure.

$\mathrm{HB}$ equation with or without correction factors in critically ill AKI patients as it was found to be inaccurate and unreliable for ICU patient [32].

It may be argued that inaccurate predictions are expected because the $\mathrm{HB}$ equation was developed long ago and based on data from healthy volunteers. Others equations as the Ireton-Jones, Penn state and Faisy have been developed from REE measurements of hospitalized and critically ill patients, and dynamic variables as body temperature and minute ventilation that reflect the metabolic state of the patient. Although they are intended to critically ill patients, several studies have found these formulas have poor agreement with measured REE by IC $[33,34]$. 
Boulatta et al. [33], evaluated energy expenditure equations in 365 hospitalized patients. They found there were poor accuracy between REE measured by IC and REE predicted by the HB, Mifflin, Penn State and the Ireton-Jones equations. In all cases, the predictive equations underestimated measured REE.

Kroos et al. [34], evaluated the REE in 927 critically ill patients, including 401 obese patients. They also found there were poor agreement between REE measured by IC and REE predicted by the HB, American College of Chest Physicians, Mifflin, and the IretonJones equations. In all cases, except using Ireton-Jones, the predictive equations underestimated measured REE.

We recently have published the paper "Poor Agreement between Predictive Equations of Energy Expenditure and Measured Energy Expenditure in Critically Ill Acute Kidney Injury Patients " that aimed to determine if six different predictive equations for estimated REE accurately reflect the requirements of AKI patients. We included in this prospective and observational study AKI patients AKIN-3 assessed by IC. Bland-Altman, intra class correlation coefficient and precision (percentagem of predicted values within $10 \%$ of measured values) were performed to compare REE by equations with REE measured by IC. None of these equations accurately estimated measured REE in severe AKI patients and most of them underestimated energy needs [35].

Our study agrees with review studies that also suggest that none of these equations has sufficient accuracy and agreement with measured REE in critically ill patients and should not replace the use of IC33. Using universal prediction equations to critical ill AKI patients, errors of prediction can occur and lead to overfeeding or underfeeding if they are used to guide the feeding regimen of these patient [36].

Using this data set, we also have demonstrated that there was no significant difference between the groups of septic patients who developed and did not developed AKI. This suggests that AKI does not affect the energy metabolism of septic patients. Similar results were observed by Schneeweiss e cols [35]. It was the only study that evaluated the REE also in AKI patients. In that study, energy metabolism was measured by IC in 86 patients with AKI and chronic kidney disease $(\mathrm{CKD})$ and in 24 control subjects. In AKI patients with sepsis, the REE was increased $(p<0.05)$. In other groups with renal failure (AKI without sepsis, CKD with conservative treatment or hemodialysis, and severe untreated azotemia) the REE was not different from those of control subjects. The authors concluded that renal failure has no influence on energy expenditure as long as septicemia is absent.

Others studies agree with our results that suggest the hypermetabolism may be present in AKI patients since AKI is a part of a more complex illness such as sepsis and not necessarily the direct consequence of renal failure per se. suggesting that AKI does not influence the energy metabolism of septic patients [15-21].

There was no significant difference in evolutional REE (day 1 vs. day 7) in general septic population and after patients have been divided into AKI and non-AKI groups. Different results were observed by Vermeij et al. [37], who investigated if only a daily measure of REE could be extrapolated for the whole length of stay in the ICU. The authors noted that there were variations higher than $31 \%$ for the same patient, although the daily average is close to the average seven-day study.

Some limitations should be recognized. First, we did not examine others predictive equations currently used in practice such as Mifflin, Penn State and the Ireton-Jones equations. However, the HB equation that we evaluated contain clinical information readily available to practitioners, making it clinically useful equation. Second, we did not have information about treatments that might influence energy expenditure and carbon dioxide production, including type of nutrition and energy intake, catecholamine, neuromuscular blocking agents, and opioids. Finally, we studied a select population of patients, our findings may not be generalizable to all AKI, or critically ill patients.

Despite limitations, this is the largest study to report that predictive HB equation does not accurately estimate REE in critically ill septic patients and that possible changes in energy metabolism observed in septic AKI patients are not directly related to AKI itself. Our findings suggest that the REE measured by IC was significantly higher than that estimated by the HB equation in both septic with and without $\mathrm{AKI}$ and that the $\mathrm{HB}$ equation using injury factor also was not precise and overestimated the REE. The lack of difference in REE between the septic patients with and without AKI suggests that AKI does not influence the REE of septic patients and that possible changes in energy metabolism observed in septic AKI patients are not directly related to AKI itself.

\section{References}

1. Padilha KG, Sousa RMC, Silva MCM, Rodrigues AS (2009) Patient's organ dysfunction in the Intensive Care Unit according to the Logistic Organ Dysfunction System. Rev Esc Enferm USP 43: 1205-1215.

2. Vincent JI, Bihari dJ, Suter PM, Bruining MD, White J, et al. (1995) The prevalence of nosocomial infection in intensive care units in Europe. Results of the European Prevalence of Infection in Intensive Care (EPIC) Study. EPIC International Advisory Committee. JAMA 274: 639-644.

3. Rangel Frausto MS, Pittet D, Costigan M, Hwang T, Davis CS, et al. (1995) The natural history of the systemic inflammatory response syndrome (SIRS). A prospective study. JAMA 273: 117-123.

4. Ostermann M, Chang RW (2007) Acute kidney injury in the intensive care unit according to RIFLE. Crit Care Med 35: 8: 1837-1843.

5. Fontoura CS, Cruz DO, Londero, LG, Vieira RM (2006) Avaliação nutricional no paciente crítico. Rev Bras Ter Intensiva 18: 298-306.

6. Flancbaum L, Choban PS, Sambucco S, Verducci J, Burge JC (1999) Comparison of indirect calorimetry, the Fick method, and prediction equations in estimating the energy requirements of critically ill patients. Am J Clin Nutr 69: 461-466.

7. Schneeweiss B, Graninger W, Stockenhuber F, Druml W, Ferenci P, et al. (1990) Energy metabolism in acute and chronic renal failure. Am J Clin Nutr 52: $596-601$.

8. Monteon FJ, Laidlaw SA, Shaib JK, Kopple JD (1986) Energy expenditure in patients with chronic renal failure. Kidney Int 30: 741-747.

9. Ikizler TA, Wingard RL, Sun M, Harvell J, Parker RA, et al. (1996) Increased energy expenditure in hemodialysis patients. J Am Soc Nephrol 7: 26462653.

10. Avesani CM, Draibe SA, Kamimura MA, Dalboni MA, Colugnati FA, et al. (2004) Decreased resting energy expenditure in non-dialysed chronic kidney disease patients. Nephrol Dial Transplant 19: 3091-3097. 
11. O'Sullivan AJ, Lawson JA, Chan M, Kelly JJ (2002) Body composition and energy metabolism in chronic renal insufficiency. Am J Kidney Dis 39: 369375

12. Bazanelli AP, Kamimura MA, Silva CB, Avesani CM, Lopes MG, et al. (2006) Resting energy expenditure in peritoneal dialysis patients. Perit Dial Int 26: 697-704.

13. Avesani CM, Draibe SA, Kamimura MA, Coluhnati FAB, Cuppari L (2004) Resting Energy Expenditure of Chronic Kidney Disease Patients: Influence of Renal Function and Subclinical Inflammation. Am J Kidney Dis 44: 10081016.

14. Avesani CM, Cuppari L, Silva AC, Sigulem DM, Cendoroglo M, et al. (2001) Resting energy expenditure in pre-dialysis diabetic patients. Nephrol Dial Transplant 16: 556-565.

15. Lopez Martinez J, Sanchez-Izquierdo Riera JA, Jimenez FJ (2011) Guidelines for specialized nutritional and metabolic support in the critically-ill patient. Update. Consensus SEMICYUC-SENPE: Acute renal failure. Nutricion Hospitalaria 26: 21-26.

16. Monson P, Mehta RL (1996) Nutritional considerations in continuous renal replacement therapies. Semin Dialysis 9: 152-159.

17. Marin A, Hardy G (2001) Practical implications of nutritional support during continuous renal replacement therapy. Curr Opin Clin Nutr Metab Care 4: 219-225.

18. Bozfakioglu S (2001) Nutrition in patients with acute renal failure. Nephro Dial Transplant 16: 21-22.

19. Kapadia FN, Bhojani K, Shah B (2003) Special issues in the patient with renal failure. Crit Care Clin 19: 233-251.

20. Druml W (2001) Nutritional management of acute renal failure. Am J Kidney Dis 37: S89-S94.

21. Bellomo R (2004) Nutritional management of patients treated with continuous renal replacement therapy. In: Kopple JD, Massry SG, eds. Kopple and Massry's Nutritional Management of Renal Disease. Philadelphia, PA Lippincott Williams \& Wilkins; 573-580.

22. Dellinger RP, Levy MM, Rhodes A, Annane D, Gerlach H, et al. (2013) Surviving Sepsis Campaign: International Guidelines for Management of Severe Sepsis and Septic Shock: 2012. Crit Care Med 41: 2: 580-637.

23. Levey AS, Bosch JP, Lewis JB, Greene T, Rogers N, et al. (1999) A More Accurate Method To Estimate Glomerular Filtration Rate from Serum Creatinine: A New Prediction Equation. Ann Intern Med 130: 6: 461-470.

24. (2012) Kidney Disease: Improving Global Outcomes (KDIGO) Acute Kidney Injury Work Group. KDIGO Clinical Practice Guideline for Acute Kidney Injury. Kidney Int 2: 1-138.
25. Liãno F, Gallego A, Pascual J, Garcia-Martin F, Teruel JL, et al. (1993) Prognosis of acute tubular necrosis: an extended prospectively contrasted study. Nephron 63: 21-23.

26. Vincent JL, Moreno R, Takala J, Willatts S, De Mendonça A, et al. (1996) The SOFA (Sepsis-related Organ Failure Assessment) score to describe organ dysfunction/failure. On behalf of the Working Group on Sepsis-Related Problems of the European Society of Intensive Care Medicine. Intensive Care Med 22: 707-710.

27. Harris JA, Benedict FG (1918) A biometric study of the basal metabolism in man. Proc Natl Acad Sci U S A 4: 12: 370-373.

28. Long CL, Schaffel BS, Geiger BA, Schiller WR, Blakemore WS (1979) Metabolic response to injury and illness: estimation of energy and protein needs from indirect calorimetry and nitrogen balance. J Parenter Enteral Nutr 3: $452-456$.

29. Chumlea WC, Guo S, Rohe AF, Steinbaugh ML (1988) Prediction of body weight for the nonambulatory elderly from anthropometry. J Am Diet Assoc 88: 564-568.

30. Coletto FA, Marson F, Campos AD, Marchini JS, Basile-Filho A (2003) Análise comparativa do gasto energético entre as equações de Harris-Benedict e de Long e a calorimetria indireta em pacientes sépticos. Rev Bras Ter Intens 15: 93-100.

31. Frankenfield D, Hise M, Malone A, Russell M, Gradwell E, et al. (2007) Prediction of resting metabolic rate in critically ill adult patients: results of a systematic review of the evidence. J Am Diet Assoc 107: 1552-1561.

32. Walker RN, Heuberger RA (2009) Predictive equations for energy needs for the critically ill. Respir Care 54: 509-521.

33. Boullata J, Willians J, Cottrell F, Hudson L, Compher C (2007) Accurate determination of energy needs in hospitalized patients. J Am Diet Assoc 107 393-401.

34. Kross EK, Sena M, Schmidt K, Stapleton RD (2012) A comparison of predictive equations of energy expenditure and measured energy expenditure in critically ill patients. J Crit Care 27: 321. e5-12.

35. Goes CR, Berbel-Bufarah MN, Sanches ACS, Xavier OS, Balbi AL, et al. (2016) Poor Agreement between Predictive Equations of Energy Expenditure and Measured Energy Expenditure in Critically III Acute Kidney Injury Patients. Ann Nutr Metab 68: 276-284.

36. Schneeweiss B, Graninger W, Stockenhuber F, Druml W, Ferenci P, et al. (1990) Energy metabolism in acute and chronic renal failure. Am J Clin Nutr 52: 596-601.

37. Vermeij CG, Feenstra BWA, van Lanschot JJB, Bruining HA (1989) Day-today variability of energy expenditure in critically ill surgical patient. Crit Care Med 17: 623-626.

Copyright: (c) 2016 Soncini Sanches AC, et al. This is an open-access article distributed under the terms of the Creative Commons Attribution License, which permits unrestricted use, distribution, and reproduction in any medium, provided the original author and source are credited. 